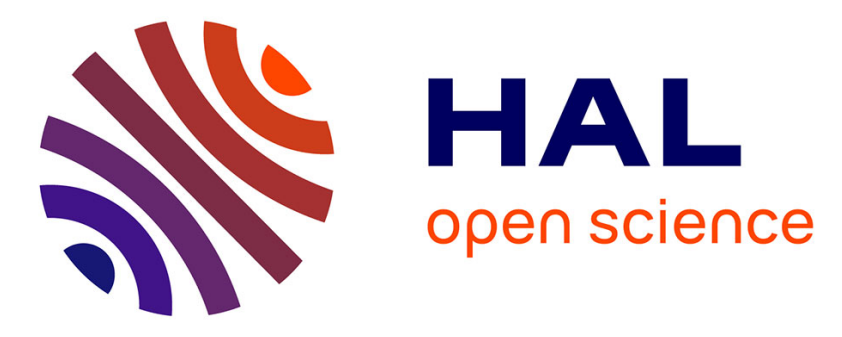

\title{
Breast meat traits of Muscovy ducks fed on a microalga (Crypthecodinium cohnii) meal supplemented diet
}

Achille Schiavone, Riccardo Chiarini, Margherita Marzoni, Annelisse Castillo, Sonia Tassone, Isabella Romboli

\section{- To cite this version:}

Achille Schiavone, Riccardo Chiarini, Margherita Marzoni, Annelisse Castillo, Sonia Tassone, et al.. Breast meat traits of Muscovy ducks fed on a microalga (Crypthecodinium cohnii) meal supplemented diet. British Poultry Science, 2007, 48 (05), pp.573-579. 10.1080/00071660701615796 . hal-00545321

\section{HAL Id: hal-00545321 \\ https://hal.science/hal-00545321}

Submitted on 10 Dec 2010

HAL is a multi-disciplinary open access archive for the deposit and dissemination of scientific research documents, whether they are published or not. The documents may come from teaching and research institutions in France or abroad, or from public or private research centers.
L'archive ouverte pluridisciplinaire HAL, est destinée au dépôt et à la diffusion de documents scientifiques de niveau recherche, publiés ou non, émanant des établissements d'enseignement et de recherche français ou étrangers, des laboratoires publics ou privés. 


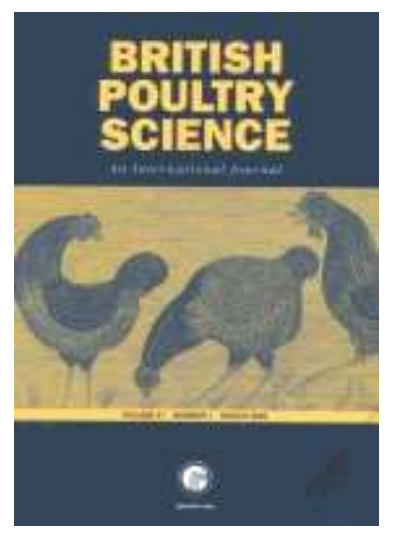

\section{Breast meat traits of Muscovy ducks fed on a microalga (Crypthecodinium cohnii) meal supplemented diet}

\begin{tabular}{|r|l|}
\hline Journal: & British Poultry Science \\
\hline Manuscript ID: & CBPS-2007-022.R1 \\
\hline Manuscript Type: & Original Manuscript \\
\hline Author: & 11 -Apr-2007 \\
\hline & $\begin{array}{l}\text { Complete List of Authors: } \\
\text { Marzoni, Margherita; Università di Pisa, Produzioni Animali } \\
\text { Castillo, Annelisse; Università di Pisa, Produzioni Animali } \\
\text { Tassone, Sonia; Università di Torino, Scienze Zootecniche } \\
\text { Romboli, Isabella; Università di Pisa, Produzioni Animali }\end{array}$ \\
\hline Keywords: & Ducks, Meat, Fats and fatty acids \\
\hline
\end{tabular}

\section{scholarONE" \\ Manuscript Central}




\section{Breast meat traits of Muscovy ducks fed on a microalga}

2 (Crypthecodinium cohnii) meal supplemented diet

3

4 A. SCHIAVONE, R. CHIARINI ${ }^{1}$, M. MARZONI ${ }^{2}$, A. CASTILLO ${ }^{1}$,

$5 \quad$ S. TASSONE ${ }^{2}$ AND I. ROMBOLI ${ }^{1}$

7 Faculty of Veterinary Medicine, Dipartimento di Produzioni Animali,

8 Epidemiologia ed Ecologia, Università degli Studi di Torino, ${ }^{1}$ Faculty of

9 Veterinary Medicine, Dipartimento di Produzioni Animali, Università degli Studi

10 di Pisa, ${ }^{2}$ Faculty of Agriculture, Dipartimento di Scienze Zootecniche, Università

11 degli Studi di Torino, Italy

12

* Correspondence address: A. Schiavone, Dipartimento di Produzioni Animali, Epidemiologia ed Ecologia, Facoltà di Medicina Veterinaria, 10095 Grugliasco (TO), Italy.

Tel.: $+39-011-6709208$

Fax: $\quad+39-011-6709240$

E-mail: achille.schiavone@unito.it Accepted for publication $15^{\text {th }}$ May 2007 
1 Abstract 1. A trial was conducted in order to increase the docosahexaenoic acid

2 (DHA) content in the meat of Muscovy ducks (Cairina moschata domestica L.)

3 fed on a diet supplemented with the microalga Crypthecodinium cohnii.

4 2. Two diets were provided to 48 male and 48 female ducks, belonging to an

5 Italian rural strain during the last three weeks of life: a maize-soybean based diet

6 as the control diet and the same diet supplemented with $5 \mathrm{~g} / \mathrm{kg}$ microalga meal.

7 3. Dietary treatment did not induce differences in growth performances and

8 slaughter traits. Similarly, chemical composition, colour, $\mathrm{pH}$, oxidative stability

9 and sensory characteristics of breast muscle were not influenced by the diet.

10 4. A significant increase of DHA content in breast meat of ducks fed on the

11 Crypthecodinium cohnii enriched diet was observed.

\section{INTRODUCTION}

13 In human nutrition, the biological effect of $n-3$ long chain polyunsaturated fatty 14 acids (LC-PUFAs) has received great interest as they play an active role in the 15 prevention and management of several pathologies such as coronary heart disease, 16 hypertension, type 2 diabetes, renal disease, ulcerative colitis, chronic obstructive 17 pulmonary disease and Crohn's disease (Simopoulos, 2000). The main molecules 18 of the n-3 LC-PUFAs family involved in the beneficial biological effects are 19 eicosapentaenoic acid (EPA, C20:5 n-3), docosapentaenoic acid (DPA, C22:5 n-3)

20 and docosahexaenoic acid (DHA, 22:6 n-3). The current Western diet is 21 characterised by low fish consumption, representing the main source of n-3 LC22 PUFAs, and a high consumption of products from terrestrial animal origin, 23 characterised by a large content of PUFAs of the n-6 series (Simopoulos, 2000).

24 On the other hand, the nutritional value of these products rich in n-6 PUFAs, such 
1 as poultry meat, could be enhanced by increasing the n-3 LC-PUFAs content. In

2 fact, several studies aimed to enrich poultry products with n-3 LC-PUFAs

3 indicated fish oil as the most effective source for this purpose (Hargis and Van

4 Elswyk, 1993; Leskanich and Noble, 1997). Our previous experience showed an

5 increase in the amount of LC-PUFAs in duck meat with dietary fish oil

6 (Schiavone et al., 2004). The recommendation of the European Union (decision

$700 / 766 / \mathrm{EU})$, concerning the ban on the use of animal proteins in animal nutrition,

8 and the consumers' preferences, stimulated the interest in making diets for birds

9 using exclusively vegetable ingredients.

10 This investigation aimed to increase the docosahexaenoic acid (DHA)

11 content of the breast muscle of Muscovy ducks. Therefore, ducks were fed on a

12 diet supplemented with marine microalga meal at the end of the finisher period.

13 The microalga Crypthecodinium cohnii, a non-photosynthetic marine

14 dinoflagellate, rich in DHA (Jiang et al., 1999) was included in the diet and its

15 effect evaluated at the minimum slaughter age for Muscovy ducks. Besides, meat

16 sensory evaluation was performed to exclude the presence of a disagreeable taste.

MATERIALS AND METHODS

\section{Animals and diets}

19 Muscovy ducklings (Cairina moschata domestica L.) of both sexes of an Italian

20 rural strain, hatched at the Experimental Avian Station of the Department of

21 Animal Production of Pisa (Italy), were used for this trial. The experimental

22 protocol was approved by the Ethics Committee of the Faculty of Veterinary

23 Medicine of Pisa, Italy. All animal housing conformed to European Union

24 guidelines. 
A total of 48 males and 48 females were distributed by sex in 6 pens,

2 respectively. Density was $3.5 \mathrm{males} / \mathrm{m}^{2}$ and 4 females $/ \mathrm{m}^{2}$. All ducks received the

3 same diet before the beginning of the experimental trial: a starter diet (12.1 MJ

$4 \mathrm{ME} / \mathrm{kg}$ and $240 \mathrm{~g}$ of crude protein $/ \mathrm{kg}$ ), and a finisher diet (12.0 MJ ME/kg and

$5200 \mathrm{~g}$ of crude protein $/ \mathrm{kg}$ ). The trial began when male ducks and female ducks

6 were 50 and $43 \mathrm{~d}$ old, respectively. During the 21-d experimental period the

7 finisher diet (Control diet, C) was compared with the same diet enriched with 5

$8 \mathrm{~g} / \mathrm{kg}$ dried microalga Crypthecodinium cohnii (Microalga diet, MA) (Algamix -

9 AG DHA $\left.{ }^{\circledR}\right)$. The two diets were formulated to be isoenergetic and

10 isonitrogenous (Table 1). Each diet was randomly assigned to three pens for each

11 sex. Olive oil was used as fat source for both diets. During the trial, individual

12 duck body weight and feed consumption per pen were recorded weekly to

13 calculate the feed conversion ratio (FCR).

Table 1 near here

\section{Carcase assessment and meat quality}

15 At the minimum slaughter age, seven 71-d old males and seven 64-d old females

16 per dietary treatment were sacrificed by electrical stunning followed by neck-

17 cutting, after a 12-h starving period. Eviscerated and plucked carcases were

18 weighted after removal of the feet and abdominal fat to obtain ready to cook

19 carcases (RCC). Breast fillets and liver were excised from refrigerated RCC (6

20 hours at $+4^{\circ} \mathrm{C}$ ) and weighed to evaluate slaughter traits.

21 Just before the dissection, $\mathrm{pH}$ and colour measurements of Pectoralis

22 major muscles were determined. $\mathrm{pH}$ was measured using a Hanna Instruments

$238417 \mathrm{pH}$-meter supplied with a Hamilton Biotrode electrode. Meat colour

24 (CIELAB system: $\left.L^{*}, a^{*}, b^{*}\right)$ was measured on breast muscle surface using a

25 Minolta Chroma-Meter CR-300 colour analyser. 
Pectoralis major muscle was vacuum-packaged and frozen $\left(-20^{\circ} \mathrm{C}\right)$ for

2 analytical and sensory determinations described below. AOAC methods (1990)

3 were used to assess moisture, ash, protein and ether extract and results were

4 expressed as percentage on a fresh matter basis. Fatty acid composition of both

5 breast muscle and diets was ascertained by capillary gas chromatography after

6 lipid extraction (Folch et al., 1957) and esterification (Christie, 1982), using

7 sodium methoxide as catalyst. Fatty acid methyl esters were analysed by a Perkin-

8 Elmer AutoSystem gas-chromatograph, equipped with a flame ionisation detector

9 and a Supelco Omegawax 320 capillary column ( $30 \mathrm{~m}$ x $0.32 \mathrm{~mm}, 0.25 \mu \mathrm{m}$ film).

10 Each fatty acid peak was identified by pure methyl ester standards (Supelco and

11 Restek Corporation, Bellefonte, PA) and data were conveyed as relative values.

12 Susceptibility to lipid oxidation was estimated from thiobarbituric acid

13 reactive substances (TBARS) according to the iron-induced TBARS procedure,

14 described by Huang and Miller (1993): $3 \mathrm{~g}$ of minced breast were homogenised in

$1557 \mathrm{ml}$ of a chilled $1.15 \% \mathrm{KCl}$ solution; $30 \mathrm{ml}$ of the homogenate were incubated

16 at $37^{\circ} \mathrm{C}$ in a shaking water bath with $8.34 \mathrm{mg} \mathrm{FeSO}_{4} \cdot 7 \mathrm{H}_{2} \mathrm{O}$ (final concentration 1

$17 \mathrm{mM} \mathrm{Fe}^{+3}$ ) as oxidative agent. The iron-induced TBARS assay was performed at 0 ,

1860 and 120 minutes of incubation and the absorbance was read at $532 \mathrm{~nm}$. Liquid

19 malonaldehyde bis (diethyl acetal) (MDA) (Aldrich Chemical Co Ltd, Dorset

20 England) was used as the standard to determine the linear standard response and

21 recovery. TBARS values were calculated by multiplying absorbance by a constant

22 coefficient K (23.58), combining standard response, recovery (93.4\%), molecular

23 weight of the MDA and sample weight. TBARS values were expressed as mg

$24 \mathrm{MDA} / \mathrm{kg}$ fresh meat. 
A sensory panel test was performed on Pectoralis major muscle, without

2 skin, roasted in a hot air oven at $165^{\circ} \mathrm{C}$ until an internal temperature of $70^{\circ} \mathrm{C}$,

3 without salt or spices and skin. Cooked samples were immediately sliced into 8

4 pieces and randomly offered to 6 trained panellists. The trial consisted of 4

5 sessions and the traits assessed were: tenderness, juiciness, fibrousnesses and

6 acceptability. A 5-point scale was used: 1 referring to very disagreeable, very

7 tough, very dry, very fibrous and 5 to very agreeable, extremely tender, very

8 juicy, without fibre (Cross et al. 1986).

$9 \quad$ Statistical analysis

10 Measurements of in vivo performances, slaughter traits, chemical composition,

11 fatty acid profile and sensory analysis of meat were split by sex and analysed with

12 a linear model including the fixed effect of diet (SPSS, 1997). Significance of

13 differences was evaluated by t-test.

\section{RESULTS}

15 Fatty acid composition of microalga meal was characterised by a $30.6 \%$ DHA

16 content. The $5 \mathrm{~g} / \mathrm{kg}$ inclusion of microalga meal in MA diet resulted in a $2.3 \mathrm{~g} / \mathrm{kg}$

17 content of DHA of total fatty acids, while DHA in the C diet was not detected

18 (Table 1). Growth performances, slaughter traits and breast muscle traits (colour,

$19 \mathrm{pH}$ and chemical composition) were not influenced by dietary treatments (Tables

202,3 and 4). Similarly, susceptibility to lipid oxidation was not affected by the

21 diet (Table 4). Besides, the inclusion of microalga did not influence tenderness,

22 juiciness, fibrousness and acceptability of meat (Table 4).

Tables 2,3,4 near here

23 Fatty acid composition of breast meat (Table 5) was affected $(P<0.05)$ by

24 the diet. In particular DHA content was significantly higher in birds fed on the

25 MA diet $(+2.9$ fold in males and +2.8 fold in females, for MA and C diet, 
1 respectively). The improvement of DHA content in breast muscles due to MA diet

2 significantly influenced the total n-3 PUFAs amount $(+1.9$ fold in males and +

31.8 fold in females, for MA and C diet, respectively) and the n-6/n-3 ratio (- 1.8

\section{DISCUSSION}

6 Our results of moisture, protein and lipid contents in breast meat, $74.6-76.8 \%$,

$720.2-21.2 \%, 0.99-1.06 \%$ respectively, are similar to those reported by other

8 authors, (Baéza et al., 1997; Baéza et al., 2002; Koci et al., 1982; Paquin, 1988). Avian fatty acids are typically monounsaturated, due to an active hepatic

10 delta-9 desaturase, and an oleic and palmitoleic acid predominance. Domestic

11 granivores use dietary carbohydrate for de novo fatty acid synthesis. Birds

12 usually, except for some species, lack the enzymatic capacity to introduce double

13 bonds past the ninth carbon of the fatty acid. Thus, they cannot use stearic acid to

14 synthesise linoleic acid or alpha-linolenic acid, which are essential fatty acids in

15 birds (Klasing, 2000). Dietary provision of lipids was shown to influence the

16 composition of phospholipid membranes and adipose depots. In fact,

17 susceptibility of avian tissues and yolk lipids to fatty acid manipulation has been

18 reviewed by Leskanich and Noble (1997) and Hargis and Van Elswyk (1993).

19 Thus, the enrichment of poultry products with n-3 fatty acids, especially those

20 with a number of carbons up to 20 , is the main goal of fatty acid manipulation.

21 Maldijan et al. (1996) showed that phospholipid fatty acid composition of eggs

22 from chicken and duck (Anas platyrhynchos L.) markedly differed. The

23 phospholipid fraction of duck eggs has higher proportions of arachidonic acid and

24 lower proportions of DHA than chicken eggs. This shows that duck liver is quiet

25 efficient at converting dietary 18:2 n-6 into 20:4 n-6, whereas in chicken the 
1 conversion of 18:3 n-3 into 22:6 n-3 has priority. Thus, variations in the fatty acid

2 profiles of yolk lipids may be derived from dietary provision of PUFAs as well as

3 genetic differences among avian species regarding liver metabolic activities.

4 However, in broiler chicken the capability to transfer LC-PUFAs from liver to

5 peripheral tissue seems to be less effective than the mechanism involved in the

6 incorporation of these in the yolk lipids. In fact Lopez-Ferrer et al. (2001) showed

7 that dietary linolenic acid (28\% of total dietary fatty acid) stimulates hepatic

8 metabolic pathways involved in the elongation and desaturation of C18:3 n-3 into

$922: 6$ n-3 (5.67\%-7.16\% of total fatty acid), resulting in an inefficient build-up in

10 thigh muscles $(0.25 \%$ of total fatty acid $)$. Similarly, in turkey, the conversion of

11 C18:3 n-3 to EPA and DHA is weak. According to Komprda et al. (2005) the

12 administration of three different diets containing $1.9 \%, 36.5 \%$ and $1.1 \%$ alpha-

13 linolenic acid resulted in $6.8 \%, 9.0 \%$ and $5.7 \%$ EPA+DHA in breast meat.

14 Dietary algae have been successfully used in the nutrition of laying hens

15 (Herber and van Elswyk, 1996; Nitsan et al., 1999; Tallarico et al., 2002), broiler

16 chickens (González-Esquerra and Leeson, 2001; Mooney et al., 1998; Sirri et al.,

17 2003a; Sirri et al., 2003b) to obtain enriched poultry products, characterised by a

18 significant amount of DHA or EPA, which could contribute to the novel concept

19 of "functional food" in human nutrition (Garg et al., 2006; Almeida et al., 2006).

20 In biological tissues and fluids, susceptibility to lipid oxidation is related to fatty

21 acid chain length, number of double bonds (Liu et al., 1997) and amount of

22 antioxidant molecules (Surai, 1999). Our data on iron-induced TBARS showed no

23 differences between groups in spite of the increase in DHA amount in animals fed

24 on the diet supplemented with the microalga meal. This might be explained by the

25 fact that the content of naturally occurring carotenoids, such as beta-carotene and 
1 canthaxanthin in the Crypthecodinium cohnii (Barclay et al., 1994), may provide

2 LC-PUFAs stabilisation due to their antioxidant properties (Surai, 2002). Other

3 authors studied the effect of other dietary microalgae on lipid stability of avian

4 meat. No differences were found by Mooney et al. (1998) in breast meat TBARS

5 values among chickens fed on $0 \%, 2.8 \%$ and $5.5 \%$ of dried Schizochytrium. Sirri

6 et al. (2003a and 2003b) studied the effect of $0.0 \%, 0.5 \%$ and $1.0 \%$ dietary

7 Schizochitrium in broiler chicken on lipid stability of both drumstick and breast

8 meat. TBARS values of drumstick meat were not influenced by dietary

9 Schizochytrium, oppositely breast meat TBARS values of the same birds receiving

$10 \quad 1.0 \%$ Schizochytrium appeared to be significantly higher than those from birds fed

11 on 0.0 and $0.5 \%$ alga meal.

12 The $5 \mathrm{~g} / \mathrm{kg}$ inclusion of Crypthecodinium cohnii did not affect the sensory

13 panel test, agreeing with the results shown by Sirri et al. (2003b) when

14 Schizochytrium were administered to chickens. Likewise Mooney et al. (1998)

15 referred no modification of flavour in fresh chicken meat, while cooked meat

16 samples from the experimental group with the highest level of Schizochytrium

17 (5.5\% of diet) were judged "undesirable".

18 In conclusion the $5 \mathrm{~g} / \mathrm{kg}$ inclusion of microalga Crypthecodinium cohnii in

19 the diet, provided for the last $21 \mathrm{~d}$ of life, improved DHA content in the duck meat

20 without negative influences on sensory traits of the breast meat.

21 Also, the dietary microalga did not negatively influence growth

22 performances or slaughter traits. In addition, chemical composition, colour, $\mathrm{pH}$

23 and oxidative stability of breast muscle were not influenced by the microalga

24 supplemented diet. Muscovy duck appeared to react positively to this dietary 
1 supplementation. Thus, the use of Crypthecodinium cohnii could be used as a

2 dietary strategy to enhance n-3 PUFA in duck meat.

In conclusion this DHA-enriched meat could contribute to human

4 nutrition, providing an increase of about three-fold in DHA content compared to

5 meat from ducks fed on a diet without microalga meal supplementation.

\section{ACKNOWLEDGEMENTS}

7 We are grateful to Mrs Manuela Baglini for duck breeding and Mrs Chiara

8 Bianchi for technical support. Acknowledgements are due to Bios Pan Srl

9 (Concordia sulla Secchia - MO, Italy) for providing the Algamix -AG DHA ${ }^{\circledR}$.

\section{REFERENCES}

11 ALMEIDA, M.D.V., PINHÃO, S., STEWART-KNOX, B., PARR, H.J, \&

12 GIBNEY, M.J. (2006). An overview of findings from a six-country European

13 survey on consumer attitudes to the metabolic syndrome, genetics in nutrition, and

14 potential agro-food technologies. British Nutrition Foundation Nutrition Bulletin, 15 31: 239-246.

16 AOAC (1990). Official methods of analysis, $14^{\text {th }}$ ed. Arlington, VA. USA: 17 Association of Official Analytical Chemistry.

18 BAÉZA, E., DE CARVILlE, H., SALICHON, M.R., \& LECLERQ, B. (1997).

19 Effect of selection, over three four generations, on meat yield and fatness in 20 Muscovy ducks. British Poultry Science, 38: 359-356.

21 BAÉZA, E., DESSAY, C., WACRENIER, G., MARCHE, G., \& LISTRAT, A. 22 (2002). Effect of selection for improved body weight and composition on muscle 23 and meat characteristics in Muscovy duck. British Poultry Science, 4: 560-568. 
1 BARCLAY, W.R., MEAGER K.M., \& ABRIL, J.R. (1994). Heterotrophic

2 production of long chain omega-3 fatty acid utilizing algae and algae-like

3 microorganisms. Journal of Applied Phycology, 6: 123-129.

4 CHRISTIE, W.W. (1982). A simple procedure for rapid transmethylation of

5 glycerolipids and cholesteryl esters. Journal of Lipid Research, 23: 1072-1075.

6 CIELAB Colour System (1976). Commission International de l'Eclairage. Paris:

7 CIE Publication.

8 CROSS, H.R., DURLAND, P.R., \& SEIDEMAN, S.C. (1986). Sensory qualities

9 of meat, in P.J. BECHTEL (Ed.), Muscle as food, pp. 279-3290 (Orlando,

10 Harcourt Brace Jovanovich).

11 FOLCH, J., LEES, M., \& SLOANE-STANLEY, H. (1957). A simple method for

12 the isolation and purification of total lipids from animal tissue. Journal of Biology

13 Chemistry, 226: 479-509.

14 GARG, M.L., WOOD, L.G., SINGH, H., \& MOUNGHAN, P.J. (2006). Mean of

15 delivering recommended levels of long chain n-3 polyunsaturated fatty acids in

16 human diets. Journal of Food Science, 71 (5): 66-71.

17 GONZÁLEZ-ESQUERRA, R., \& LEESON, S. (2001). Alternatives for

18 enrichment of eggs and chicken meat with omega-3 fatty acids. Journal of Animal

19 Science, 81 (3): 295-305.

20 HARGIS, P.S., \& VAN ELSWYK, M.E. (1993). Manipulation of fatty acid

21 composition of poultry meat and eggs for the health conscious consumer. World's

22 Poultry Science Journal, 49: 257-264.

23 HERBER, S.M., \& VAN ELSWYK, M.E. (1996). Dietary marine algae promotes

24 efficient deposition of n-3 fatty acids for the production of enriched shell eggs.

25 Poultry Science, 75: 1501-1507. 
1 HUANG, Y.X., \& MILLER, E.L. (1993). Iron-induced TBARs as an indicator of

2 oxidative stability of fresh chicken meat. Proceedings of the $11^{\text {th }}$ European

3 Symposium on the Quality of Poultry Meat, Tours, pp 478-484.

4 JIANG, Y., CHEN, F., \& LIANG, S.-Z. (1999). Production potential of

5 docosahexaenoic acid by the heterotrophic marine dinoflagellate Crypthecodinium

6 cohnii. Process Biochemistry, 34: 633-637.

7 KLASING, K.C. (2000). Lipids, in: KLAISING, K.C. (Eds) Comparative avian

8 nutrition, pp 171-173 (CAB International, Cambridge, UK).

9 KOCI, E., BAUMGARTNER, J., ILLES, V., \& PALANSKA, O. (1982). Carcass

10 and nutritive value of the small white broiler duck and its crosses. Archiv für

11 Geflügelkunde, 46: 157 - 163.

12 KOMPRDA T., ZELENKA J., FAJMONOVA E., FIALOVA M. \& KLADROBA

13 D. (2005). Arachidonic acid and long-chain n-3 polyunsaturated fatty acid

14 contents in meat of selected poultry and fish species in relation to dietary fat

15 sources, Journal of Agricultural and Food Chemistry, 53: 6804-6812.

16 LESKANICH, C.O., \& NOBLE, R.C. (1997). Manipulation of n-3

17 polyunsaturated fatty acid composition of avian eggs and meat. World's Poultry

18 Science Journal, 53: 155-183.

19 LIU, J., YEO, H.C., DONIGER, S.J., \& AMES, B.N. (1997). Assay of aldehydes

20 from lipid peroxidation: gas chromatography-mass spectrometry compared to

21 thiobarbituric acid. Analytical Biochemistry, 14, 245: 161-166.

22 LOPEZ-FERRER, S., BAUCELLS, M.D., BARROETA, A.C., GALOBART, J.,

23 \& GRASHORN, M.A. (2001). n-3 enrichment of chicken meat. Use of precursors

24 of long-chain polyunsaturated fatty acids: linseed oil. Poultry Science 80: 75325761. 
1 MALDiJAN, A., CRISTOFORI, C., NOBLE, R.C., \& SPEAKE, B.K. (1996).

2 The fatty acid composition of brain phospholipids from chicken and duck

3 embryos. Comparative Biochemistry and Physiology B, 115B: 153-158.

4 MOONEY, J.W., HIRSCHLER, E.M., KENNEDY, A.K., SAMS, A.R., \& VAN

5 ELSWYK, M.E. (1998). Lipid and flavour quality of stored breast meat from

6 broilers fed marine algae. Journal Science of Food Agriculture, 78: 134-140.

7 NITSAN, Z., MOKADY, S., \& SUKENIK, A. (1999). Enrichment of poultry

8 products with n-3 fatty acids by dietary supplementation with the alga

9 Nannochloropsis and mantur oil. Journal of Agriculture Food Chemistry, 47:

$10 \quad 5127-5132$.

11 PAQUIN, J. (1988). Valeur nutritionelle des viandes de volailles, in ROSSET, R.

12 (Ed.) L'aviculture française. Informations Techniques des Services Vétérinaires

13 (Paris).

14 SCHIAVONE, A., ROMBOLI, I., CHIARINI, R., \& MARZONI, M. (2004).

15 Influence of dietary lipid source and genotype on fatty acid composition of 16 Muscovy duck meat. Journal of Animal Physiology and Animal Nutrition, 88: 881793.

18 SIMOPOULOS, A.P. (2000). Human requirement for $n-3$ polyunsaturated fatty 19 acid, Poultry Science, 79: 961-970.

20 SIRRI, F., MINELli, G., IAFFALDANO, N., TALLARICO, N., \& 21 FRANCHINI, A. (2003a). Oxidative stability and quality traits of n-3 PUFA 22 enriched chicken meat. Italian Journal of Animal Science, 2(1): 450-452.

23 SIRRI, F., MINELli, G., MELUZZI, A., \& FRANCHINI, A. (2003b). Quality 24 traits and oxidative stability of n-3 PUFA enriched meat, in: BAEZA, E. \& 
1 FERNANDEZ, X. (Eds.). Proceedings of the XVI European Symposium on the

2 Quality of Poultry Meat, Saint-Brieuc, pp. 258-264.

3 SPSS (1997). Guida dell'utente SPSS, base 7.5 per Windows ${ }^{\circledR}$. (Inc. Chicago,

4 Illinois. U.S.A.).

5 SURAI, P.F. (1999) Vitamin E in avian reproduction. Poultry and Avian Biology

6 Reviews, 10 (1), 1-60.

7 SURAI, P.F. (2002) Carotenoids in natural antioxidants in avian nutrition and

8 reproduction. Nottingham University Press (U.K), pp 129-200.

9 TAllariCO, N., SIRRI, F., MELUZZI, A., PITTIA, P., PERPINELLO, G.P., \&

10 FRANCHINI, A. (2002). Effect of dietary vegetable lipids on functional and

11 sensory properties of chicken eggs. Italian Journal of Food Science, 14 (2): 159-

12166. 
Table 1. Ingredients, chemical and fatty acid composition of the diets

\begin{tabular}{|c|c|c|}
\hline \multirow{3}{*}{ Ingredients $(\mathrm{g} / \mathrm{kg})$} & \\
\hline & \multicolumn{2}{|c|}{$\begin{array}{l}\text { Experimental period } \\
\text { (last } 21 \text { d of life) } \\
\text { C diet MA diet }\end{array}$} \\
\hline & & \\
\hline Maize meal & 598 & 602 \\
\hline Soybean meal & 340 & 333 \\
\hline Dicalcium phosphate & 20 & 20 \\
\hline Calcium carbonate & 17 & 17 \\
\hline Sodium chloride & 2 & 2 \\
\hline DL-methionine & 2 & 2 \\
\hline L-lysine & 1 & 1 \\
\hline Vitamin and mineral premix ${ }^{a}$ & 5 & 5 \\
\hline Olive oil & 15 & 13 \\
\hline $\begin{array}{l}\text { Crypthecodinium cohnii meal } \\
\text { Chemical composition }(\mathrm{g} / \mathrm{kg})\end{array}$ & - & 5 \\
\hline Dry matter & 878.1 & 878.6 \\
\hline Crude protein & 200.1 & 202.6 \\
\hline Ether extract & 34.4 & 37.3 \\
\hline Crude fibre & 29.2 & 31.4 \\
\hline Ash & 67.7 & 63.2 \\
\hline Metabolisable energy $(\mathrm{MJ} / \mathrm{kg})$ & 12.09 & 12.07 \\
\hline $\begin{array}{l}\text { Fatty acid composition } \\
\text { (g/100 g fatty acid) }\end{array}$ & & \\
\hline $\mathrm{C} 14: 0$ & 0.11 & 0.31 \\
\hline C16:0 & 13.89 & 13.92 \\
\hline $\mathrm{C} 16: \ln 7$ & 0.33 & 0.34 \\
\hline C18:0 & 3.06 & 2.81 \\
\hline C18:1n9ct & 31.84 & 31.80 \\
\hline $\mathrm{C} 18: 2 \mathrm{n} 6 \mathrm{c}$ & 45.19 & 45.45 \\
\hline C18:3n3 & 1.99 & 1.72 \\
\hline C22:6n3 & - & 0.23 \\
\hline $\mathrm{SFAs}^{\mathrm{b}}$ & 17.96 & 17.98 \\
\hline $\mathrm{UFAs}^{\mathrm{c}}$ & 79.81 & 79.65 \\
\hline SFAs/UFAs & 0.23 & 0.23 \\
\hline MUFAs $^{\mathrm{d}}$ & 32.38 & 32.45 \\
\hline PUFAs $^{\mathrm{e}}$ & 47.43 & 47.20 \\
\hline n6 & 45.48 & 45.22 \\
\hline n3 & 1.95 & 1.99 \\
\hline $\mathrm{n} 6 / \mathrm{n} 3$ & 23.00 & 23.00 \\
\hline
\end{tabular}

3 a provided per kg of diet: retinol $3 \mathrm{mg}$; cholecalciferol, $45 \mathrm{mg}$; DL- $\alpha$-tocopheryl acetate $30 \mathrm{mg}$; thiamine $1.5 \mathrm{mg}$; riboflavin $3 \mathrm{mg}$; pyridoxine $1.5 \mathrm{mg}$; cobalamin $0.015 \mathrm{mg}$; pantothenic acid $8.0 \mathrm{mg}$; niacin $25 \mathrm{mg}$; choline chloride $500 \mathrm{mg}$; $\mathrm{Fe}\left(\mathrm{FeSO}_{4}\right.$

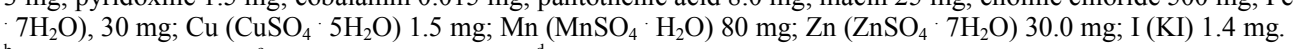
${ }^{\mathrm{b}}$ saturated fatty acids; ${ }^{\mathrm{c}}$ unsaturated fatty acids; ${ }^{\mathrm{d}}$ monounsaturated fatty acids; ${ }^{\mathrm{e}}$ polyunsaturated fatty acids. 
Table 2. Effects of microalga meal incorporation in diets for 3 weeks on growth performance of Muscovy ducks (means, $n=24$ )

3

\begin{tabular}{|c|c|c|c|c|c|c|c|c|c|}
\hline & & \multicolumn{2}{|c|}{ Females } & \multirow[b]{2}{*}{ SEM } & \multirow[b]{2}{*}{$P$} & \multicolumn{2}{|c|}{ Males } & \multirow[b]{2}{*}{ SEM } & \multirow[b]{2}{*}{$P$} \\
\hline & & $\mathrm{C}$ & MA & & & $\mathrm{C}$ & MA & & \\
\hline Initial age & d & 43 & 43 & & & 50 & 50 & & \\
\hline Final age & $d$ & 64 & 64 & & & 71 & 71 & & \\
\hline Initial $\mathrm{LW}^{\mathrm{a}}$ & $\mathrm{g}$ & 1343 & 1369 & 21.05 & ns & 2314 & 2318 & 32.64 & $\mathrm{~ns}$ \\
\hline Final LW & $\mathrm{g}$ & 1893 & 1909 & 22.72 & ns & 3314 & 3339 & 41.55 & ns \\
\hline $\begin{array}{l}\text { Total body } \\
\text { weight gain }\end{array}$ & g & 550 & 540 & 11.44 & ns & 1000 & 1021 & 24.34 & ns \\
\hline $\mathrm{ADG}^{\mathrm{b}}$ & $\mathrm{g}$ & 26.20 & 25.71 & 0.54 & ns & 47.64 & 48.62 & 1.16 & $\mathrm{~ns}$ \\
\hline $\mathrm{FCR}^{\mathrm{c}}$ & & 5.31 & 5.03 & 0.11 & ns & 4.36 & 4.00 & 0.11 & $\mathrm{~ns}$ \\
\hline
\end{tabular}

4

5 a Live body weight.

$6{ }^{\mathrm{b}}$ Average daily weight gain.

$7 \quad{ }^{\mathrm{c}}$ Feed conversion ratio ( $\mathrm{n}=3$ for females; $\mathrm{n}=4$ for males). 
1 Table 3. Effects of microalga meal incorporation in diets for 3 weeks on slaughter 2 3 traits of Muscovy ducks (means, $n=7$ )

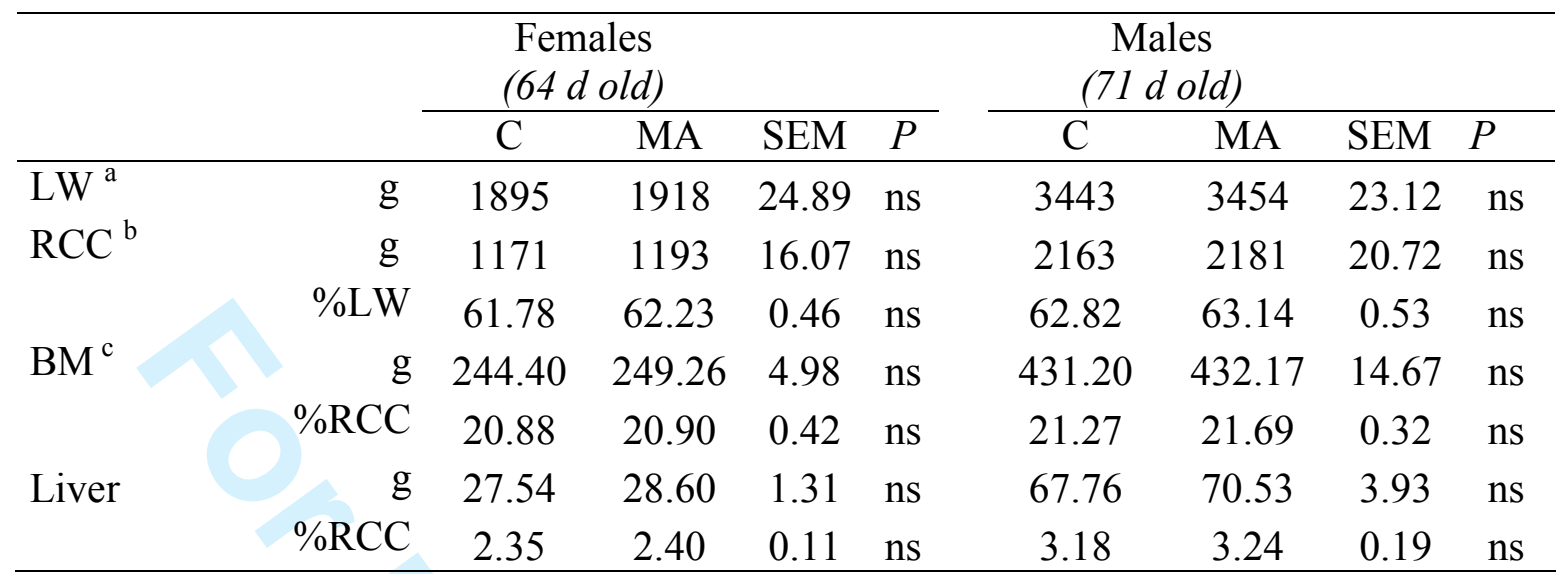

$4 \quad{ }^{\mathrm{a}}$ Live body weight.

$5 \quad$ beady to cook carcase.

$6 \quad{ }^{\mathrm{c}}$ Breast muscles. 
Table 4. Effects of microalga meal incorporation in diets for 3 weeks on physicochemical characteristics, oxidation susceptibility and sensory traits of the Pectoralis major muscle from Muscovy ducks (means, $n=7$ or 5 for chemical composition)

5

\begin{tabular}{ccccccccc}
\hline & \multicolumn{4}{c}{ Females } & \multicolumn{4}{c}{ Males } \\
& C & MA & SEM & $P$ & C & MA & SEM & $P$ \\
\hline $\mathrm{pH}^{\mathrm{a}}$ & & & & & & & & \\
& 5.64 & 5.67 & 0.04 & ns & 5.75 & 5.69 & 0.03 & ns
\end{tabular}

Chemical composition $^{\text {a }}$

$\begin{array}{lllllllll}\text { Moisture - \% } & 74.61 & 75.20 & 0.22 & \text { ns } & 76.77 & 76.57 & 0.09 & \text { ns }\end{array}$

$\begin{array}{lllllllll}\text { Protein }-\% & 21.15 & 20.90 & 0.11 & \text { ns } & 20.59 & 20.17 & 0.20 & \text { ns }\end{array}$

$\begin{array}{lllllllll}\text { Fat }-\% & 1.06 & 1.00 & 0.09 & \text { ns } & 0.99 & 1.02 & 0.06 & \text { ns }\end{array}$

$\begin{array}{lllllllll}\text { Ash }-\% & 1.35 & 1.36 & 0.02 & \text { ns } & 1.23 & 1.26 & 0.02 & \text { ns }\end{array}$

Iron-induced TBARS (mg MDA $\mathrm{kg}^{-1}$ meat) ${ }^{\mathrm{a}}$

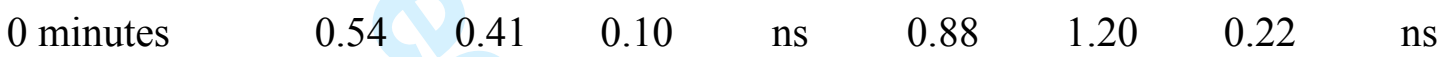

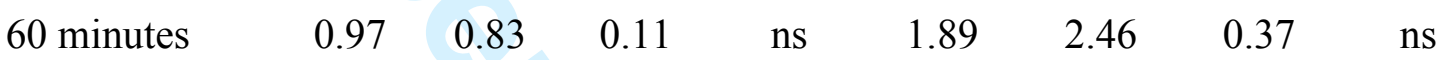

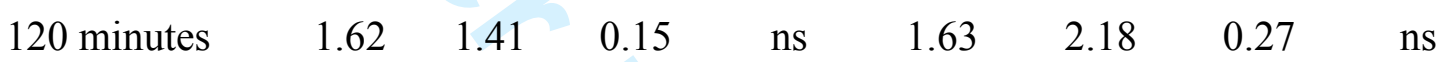

Colour $^{\text {a }}$

$\begin{array}{lcccccccc}L^{*} & 44.95 & 45.14 & 0.55 & \mathrm{~ns} & 46.28 & 46.84 & 0.41 & \mathrm{~ns} \\ a^{*} & 17.71 & 17.98 & 0.54 & \mathrm{~ns} & 17.07 & 16.68 & 0.30 & \mathrm{~ns} \\ b^{*} & 5.46 & 5.54 & 0.29 & \mathrm{~ns} & 4.53 & 4.70 & 0.36 & \mathrm{~ns}\end{array}$

Sensory traits ${ }^{b}$

$\begin{array}{lllllllll}\text { Tenderness } & 3.48 & 3.35 & 0.09 & \text { ns } & 3.35 & 3.21 & 0.13 & \text { ns }\end{array}$

$\begin{array}{lllllllll}\text { Juiciness } & 3.39 & 3.08 & 0.14 & \text { ns } & 2.73 & 2.78 & 0.17 & \text { ns }\end{array}$

$\begin{array}{llllllllll}\text { Fibrousness } & 3.32 & 3.04 & 0.13 & \text { ns } & 2.62 & 2.55 & 0.10 & \text { ns }\end{array}$

$\begin{array}{lllllllll}\text { Acceptability } & 3.03 & 2.96 & 0.15 & \text { ns } & 2.48 & 2.83 & 0.103 & \text { ns }\end{array}$

6 a results are means of two replicate analyses.

7 b each value is the mean of the judgement of 4 panellists. 
Table 5. Effects of microalga meal incorporation in diets for 3 weeks on fatty acid composition (\% of total fatty acids) of the Pectoralis major muscle from Muscovy ducks (means, $n=3$, results are means of three replicates analyses)

\begin{tabular}{|c|c|c|c|c|c|c|c|c|}
\hline & \multicolumn{4}{|c|}{ Female } & \multicolumn{4}{|c|}{ Male } \\
\hline & $\mathrm{C}$ & MA & SEM & $P$ & $\mathrm{C}$ & MA & SEM & $P$ \\
\hline C14:0 & 0.35 & 0.38 & 0.02 & ns & 0.36 & 0.33 & 0.04 & ns \\
\hline C16:0 & 24.57 & 24.57 & 0.71 & ns & 24.00 & 22.36 & 0.55 & ns \\
\hline $\mathrm{C} 16: \ln 7$ & 1.27 & 1.17 & 0.16 & ns & 2.09 & 1.40 & 0.45 & ns \\
\hline C18:0 & 12.82 & 12.48 & 0.78 & ns & 12.29 & 13.17 & 0.76 & ns \\
\hline $\mathrm{C} 18: \ln 9 \mathrm{ct}$ & 23.75 & 23.11 & 1.48 & ns & 23.73 & 23.31 & 1.73 & ns \\
\hline C18:1n7 & 2.81 & 2.52 & 0.08 & ns & 2.64 & 2.44 & 0.16 & ns \\
\hline $\mathrm{C} 18: 2 \mathrm{n} 6 \mathrm{c}$ & 16.85 & 17.03 & 0.45 & ns & 15.08 & 16.38 & 1.12 & ns \\
\hline C18:3n3 & 0.36 & 0.36 & 0.05 & ns & 0.33 & 0.34 & 0.03 & ns \\
\hline $\mathrm{C} 20: 4 \mathrm{n} 6$ & 8.87 & 9.10 & 0.96 & ns & 9.90 & 9.85 & 0.42 & ns \\
\hline C20:5n 3 & 0.06 & 0.11 & 0.02 & ns & 0.08 & 0.12 & 0.01 & ns \\
\hline $\mathrm{C} 22: 4 \mathrm{n} 6$ & 1.99 & 1.80 & 0.21 & ns & 2.14 & 1.77 & 0.13 & ns \\
\hline C22:5n6 & 1.24 & 1.04 & 0.15 & ns & 1.20 & 0.96 & 0.11 & ns \\
\hline$C 22: 5 n 3$ & 0.40 & 0.39 & 0.07 & ns & 0.47 & 0.44 & 0.04 & ns \\
\hline C22:6n3 & 0.70 & 1.97 & 0.11 & $<0.05$ & 0.74 & 2.12 & 0.18 & $<0.05$ \\
\hline $\mathrm{SFAs}^{\mathrm{a}}$ & 38.08 & 37.82 & 0.26 & ns & 37.01 & 36.25 & 0.37 & ns \\
\hline $\mathrm{UFAs}^{\mathrm{b}}$ & 60.06 & 61.73 & 0.40 & ns & 60.28 & 61.54 & 0.75 & ns \\
\hline SFAs/UFAs & 0.63 & 0.62 & 0.01 & ns & 0.61 & 0.59 & 0.01 & ns \\
\hline MUFAs $^{c}$ & 28.55 & 27.80 & 1.52 & ns & 29.13 & 27.80 & 2.05 & ns \\
\hline PUFAs $^{\mathrm{d}}$ & 31.51 & 32.93 & 1.40 & ns & 31.16 & 33.74 & 1.80 & ns \\
\hline n6 & 29.98 & 30.10 & 1.25 & ns & 29.50 & 30.65 & 1.61 & ns \\
\hline n3 & 1.53 & 2.83 & 0.16 & $<0.05$ & 1.66 & 3.09 & 0.21 & $<0.05$ \\
\hline n6/n3 & 19.85 & 10.65 & 1.05 & $<0.05$ & 17.84 & 9.98 & 0.67 & $<0.001$ \\
\hline
\end{tabular}

